\title{
Innovation and Construction of Practice Teaching for Training Excellent Engineers in Local Colleges and Universities
}

\author{
Sun Jianmin ${ }^{1, a}$, Ni Xin ${ }^{1, b}$ and Yang Yun ${ }^{1, c}$ \\ ${ }^{1}$ Beijing University of Civil Engineering and Architecture, Beijing, 100044, China \\ a jianminsun@tom.com, ${ }^{\mathrm{b}}$ nixin082@163.com, ${ }^{\mathrm{c}}$ 1264345924@qq.com
}

Keywords: local universities and colleges, civil engineering specialty, practice teaching, excellent engineer, innovation education

\begin{abstract}
According to analyzing the features of local universities and professional civil engineering, the innovative practice teaching method of civil engineering are explored in local universities. In the construction and management of innovation practice teaching, the close combination of school practice teaching and enterprise engineering and guarantee the effective implementation of the excellent engineer plan in learning stage in enterprises is promoted by the infrastructure construction, teaching system construction, the teaching practice base construction of practice teaching. Based on characteristics of their own conditions, institutional environment and history in local university, the way of training excellent engineer is exported in depth with local and school characteristics, which is the effective approach to guarantee the quality of cultivating excellence engineer.
\end{abstract}

\section{Introduction}

The training plan of excellent engineers' education is an important project about higher engineering education, which is actualized for these strategic deployments such as going a new path of industrialization with Chinese characteristicsand, building an innovation-oriented country and a powerful country of human resources being implemented[1]. Beijing University of Civil and Architecture is one of local universities in which the country implement excellent plan, the serious exploration and practice has been carried on in architecture, civil engineering, water supply and drainage science and engineering, energy and power engineering this four majors.

The cultivation of outstanding engineers mainly reflects on the cultivation practice innovation ability. Taking the actual project as the background, with engineering technology as the main line, industry and enterprise participating in depth, to improve role of enterprise plays in the talents training process and elaborate advantages in enterprise engineering environment and engineering practice, so that the cultivation of students' ability of engineering practice, the engineering design ability and creative ability has been strengthen and the quality of the talent training can be guaranteed. [2-4].

The local high school affiliated to the local government, there are regional characteristics in the recruitment of students, students source, professional settings, school scale, school effectiveness, student employment etc. The local colleges and universities are combined closely with the local economic construction, which become the main force in local higher education and science and technology by basing on the local, local service, concentrating advantage power of science and technology to solve various problems[5]. At the same time, local governments and enterprises and institutions create conditions for training and research combined to help the school to improve the quality of education and scientific research ability. In the process of development, a good relationship of promoting each other is formated between the school and the local economic construction. Practice shows that local university and college have a significantly difference with those organized by province and department, so, its power and resources is from local and seved for the local. 


\section{Construction of Practice Teaching for Training Talent Engineer}

In the process of teaching in undergraduate education, engineering education to students has important significance. In the engineering education process, it is to break the shackles of traditional thinking, stimulate the students' enthusiasm to create, cultivate the talents having engineering innovation consciousness, innovation ability and practice ability. All the teaching activities and research must take the project as the core, which is from engineering, rely on engineering, direct engineering and reverse engineering[6-8].

Strengthen the comprehensive innovation design ability. Improving innovative ability, not only depends on the innovation education theory course study, but need some more innovation activities as support, so that the students cultivate the ability in the competition, improve in the practice of scientific research and grow in social sports cultural activities. Encourage and motivate students to actively take part in the competition is to let the student realize the pleasure of your major. Setting academic and interesting in a body is an effective way to improve students' innovative ability. Positive competition events can also strengthen the exchanges and cooperation between the colleges and universities and achieve common progress. Students are encouraged to participate in Cupchallenge, business competition, architectural design competition, structure, mechanical innovation design competition, mathematical modeling race, such as robot competition comprehensive games.

Construct practice teaching collaboration system based on excellent engineers plan. According to the current distribution of discipline in our school, civil engineering specialty is a school characteristics, such as civil engineering, architecture, building environment and energy application engineering, water supply and drainage science etc. In the process of practice teaching,by the deep participation of relevant enterprises and industry in the training process, the school according to general standards and industry standard culturing engineering talents, strengthening to cultivate the students' engineering ability and innovation ability and so on to build mutual collaboration practice teaching system, mainly reflected in practice teaching system based on four professions above on the collaboration of reform and the collaboration and updation of the content of engineering practice.

College and enterprise guide graduation design together. Through the practice in stages, joint graduation design in the enterprise, students will be familiar with basic methods of civil engineering design and construction and project management and improve the comprehensive ability to use knowledge. For understanding the engineering practice, cultivating engineering comprehensive ability such as profession quality, analysis ability, communication ability, unity cooperation ability, management ability, then students have ability to independent engage in a direction in the field of civil engineering like project design, construction, operation, management and decision-making, to meet the needs of future technology development and social progress, to be outstanding talent with practical ability, innovation ability, international vision and leadership consciousness infuture

Through the graduation design, the basic knowledge and professional knowledge the student has learned can be consolidated and deepen the students' knowledge structure will be improved; the ability of information access being cultivated, students are made to understand the capital of the country's construction principles, policies and regulations, and use correctly the relevant technical standards and norms; Training students' ability of computer application, written and oral communication; Train students' correct design ideas and technical and economic view, as well as the theory with practical work, innovative spirit, serious scientific attitude; Expand overseas of students.

To carry out various forms of innovation activities. Innovation practice teaching link is strengthen that competition, scientific research training, the social sports cultural activities and communities as a key to promote the close combination of classroom teaching, practical teaching. Build a multi-level, many methods of college students' innovative ability training system. A research-type learning and innovative experiment plan is set up to strengthen the open experiment, then to encourage college students to participate in teachers' scientific research project or related 
scientific research practice of design and research institute, to increase college students' extracurricular innovation credit requirements as well as to the excellent students, such as special immortal the tutorial training policy, to construct the college students' innovative ability training system has its own characteristic, to strive to cultivate students' innovative ability and scientific literacy in the civil engineering college.

\section{Construction and Management of Innovative Practice Teaching}

Base and system construction of Innovation practice teaching. Innovation practice base is a place for student's innovation activities which supported by the school. It is based on the professional laboratory that to establish innovation base laboratory, training center, and machine room with complete software. In order to ensure the innovation activities carried out smoothly, it also set up a teacher evaluation mechanism and student organizations to create conditions for the project approval and assessment.

Advocating the teaching mode that "students practice" as main line "teacher education"seond and giving full play to the role of graduate students in innovative practice, not only to make up for the shortage of teachers, but also conducive to the student exchanges between the different grade. In order to facilitate the teachers' guidance to students and improve the guidance effect, from the beginning of sophomore students, the tutorial system of the " bi-directional selection" will be used for students as an exploration, to build a platform for communication between teachers and students and promote the effective development of innovative activities.

Innovate the cooperation forms between university and enterprise, establish the two-way internal and external teaching practice base. In the real engineering environment, students design and operate the project, focus on repeated training of the civil engineering specialty occupation behavior, which is to realize the organic combination of teaching and training, learning and working, the theory and the practice on the practice base outside the school. At the same time, establish and improve related specialty laboratory in the school, bring in enterprises accord with the direction of the development of professional, establish a integration teaching environment of a real project in the school, formation a school teaching practice base, make the major elements into the teaching practice base training center, let the students learning and training in professional in simulation engineering environment[9].

Use enterprise management concepts to improve teaching management, to promote the combination of school education and enterprise engineering construction. During the process of construction practice base, the concept of enterprise management is refered and the enterprise culture is introduced, the enterprise operation and management mode is selective applicated and the practice teaching management implemented to enable students develop good quality of engineering and management in an enterprise environment.The construction of the professional education which focuses on ability is simultaneous with the enterprise project; It promote the combination of school education and enterprise engineering project construction.

Make full use of the Chinese- foreign cooperative education platform and platform of scientific research practice. Beijing University of Civil Engineering and architecture make full use of the cooperative education projects named "China- America 2+2" with America Auburn University, and the establishment of the China-French energy training center which is a joint with France's group. We train excellent engineer from foreign experience, especially the practical teaching experience, to enrich teaching contents, and at the same time, use of student exchange programs send students abroad to have practice or short-term practice. In addition, the students participate in the teacher's scientific research and engineering practice project, or under the guidance of teachers, to declare and participate in a variety of technological innovation activities, academic competition, social practice and other forms of practical activities.

\section{Summary}


In the regional economic and social development process, it is worth to explore and solve that the local colleges and universities how to cultivate students' engineering thought, engineering knowledge, engineering quality and improve students' ability of engineering design and innovation according to the needs of local economic and social development.

(1) By the characteristics analysis of outstanding engineers training plan and local colleges and universities, it is training senior personnel who can adapt to the adjustment of business structure, be familiar with project management and have innovative ability $t$ is the central work of personnel training in colleges and universities.

(2) By the link of strengthening the engineering education and practice, a cooperation mode for practice teaching between civil engineering professionals which based on outstanding engineers plans can be built. It is aimed at cultivating students' innovation ability and constructing a practice teaching system which targets to cultivating students' engineering ability and innovation ability.

(3) In the construction and management process of practice teaching innovation, that the infrastructure construction and the teaching practice base construction for practice teaching system is to promote the combination of school practice teaching and enterprise engineering and guarantee the effective implementation plan of excellent engineer in learning enterprises.

Based on characteristics of condition, system environment and history, that exploring the ways of training excellent engineer with characteristics of local and school is an effective method to guarantee the training quality of engineers.

\section{Acknowledgements}

This work was financially supported by the Education and Teaching Research Project of China Construction Education Association (2013060) and the High School Education and Teaching Reform Project of Beijing Municipal Education Commission (2013148).

\section{References}

[1] Ministry of Education. On the Implementation of Excellent Engineer Education Opinions Plans. (high [2011]NO.1).

[2] Jian Lin. Pay Attention to Personnel Training Mode of Engineering Excellence Education Innovation Project. Chinese Higher Education(2011), p.19-21.

[3] Jinling Chen, Qiao liang. Research on Mode of Training Excellent Engineer Professional Civil Engineering College. Chinese Construction Education, 6 (2010) , p.35-39

[4] Huan Lei ,Weidun Tang, Edward Crawly. Cultivation of Innovative Talents of Science and Technology, Engineering Professional - CDIO Engineering Education Reform Concept of Talent and Training Mode. Research in Higher Education of Engineering, (2009), p.29-35.

[5] Song Xia. The Reform Trend of Civil Engineering Specialty in Local Universities Plan from the Excellent Engineer Education. Scientific and Technical Information(2011), p. 145-146.

[6] Y. LIU,Y. ZHANG.Optimation Research for a High Pressure Common Rail Diesel Engine Based on Simulation, International Journal of Automotive Technology, 11(2010), p.625-636

[7] Gang wang. Understanding and thinking of CDIO engineering education model. China Higher Education Research(2009), p.86-87.

[8] Jun Cui. Regression of Engineering Practice, in: Curriculum Reform of Higher Engineering Education Research in China. edited by Nanjing university, Nanjing,2011.

[9] Yongfeng LIU ,Pucheng PEI, Asymptotic Analysis on Autoignition and Explosion Limits of Hydrogen-Oxygen Mixtures in Homogeneous Systems, International Journal of Hydrogen Energy,31(2006),p.639-647 